UDK: 336.025

DOI: $10.1515 /$ jcbtp-2016-0021

Journal of Central Banking Theory and Practice, 2016, 3, pp. 79-98

Received: 5 May 2016; accepted: 8 July 2016

Milena Vučinić*

\title{
Importance of Macroprudential Policy Implementation for Safeguarding Financial Stability
}

\begin{abstract}
The crisis pointed to the necessity for strong and stable financial system resistant to potential risks and shocks. Macroprudential policy is used to identify, monitor and asses systemic risks to financial stability. Therefore, it is very important to create effective and efficient macroprudential policy. To achieve this, it is crucial to create a strong institutional framework.
\end{abstract}

This paper deals with the importance of macroprudential policy for financial system stability. The first part of the paper explains the macroprudential policy and its connection with other economic policies. The second part refers to the necessity of building strong institutional framework and the importance of providing clear responsibilities for macroprudential policy, as long as precise determination of responsibilities is very suggested and important for further functioning and policy implementation. Responsibilities for macroprudential policy and macroprudential supervision defers among countries.

Key words: macroprudential policy, financial stability, economic policies, institutional framework

JEL Classification: E52, E58, E61, E62, G18

\section{Introduction}

Global financial crisis revealed potential problems and gaps in institutional frameworks, including the field of macroprudential policy. The crisis showed that institutions responsible for supervision of txe financial sector lack in appropri- 
ate mandates, analytical tools and instruments for systemic risk identification. (ESRB, 2015a) The рецент crisis showed that price stability solely does not guarantee macroeconomic stability and therefore the financial stability must be provided.

The ultimate objective of macroprudential policy is safeguarding financial stability, strengthening the resilience of the financial system and decreasing the buildup of systemic risks. Stable financial system contributes to sustainable economic growth. (ESRB, 2013a) Financial stability is a precondition for a sound financial system which contributes to sustainable economic growth. The last financial crisis has revealed the need for deeper macroprudential oversight that mitigates and prevents systemic risk in the financial system. The resilience against systemic risks depends on establishing a sound macro-prudential policy framework alongside with effective micro-prudential supervision. (ESRB, 2013a)

Macroprudential policy is used to identify, monitor, and asses systemic risks to financial stability. The origins of the term macroprudential policy already show the main target and objective of the policy. "Macro" refers to preserving the stability of financial system as a whole using the instruments of regulation and supervision (this is what is meant by "prudential"). Even though financial and monetary policy can influence financial stability, macroprudential policies differ from the latter, primarily in its instruments. Macroprudential supervision is supposed to thoroughly analyse the risk and stability situation within a financial system. (DNBa)

\section{Why Macroprudential policy}

Institutions, central banks and other responsible financial institutions need clear policies and tools in order to implement its tasks and activities effectively and efficiently. Therefore, a clear and detailed macroprudential policy is necessary to support stability of the banking sector as well as the entire financial sector. It is obvious that, generally, macroprudential policies refer primarily to the banking sector and the evidence show that it will be useful to expand it to the other sectors in order to mitigate development of shadow banking and strengthen the supervision of other sectors.

Recently, many countries have experienced severe financial crises that resulted from boom-bust cycles in credit and assets. In order to respond to such difficult situations, authorities in many countries had implemented macroprudential policies as a first line of defence against financial instability risks. Some examples 
of macroprudential tools employed are counter-cyclical capital requirements, dynamic loan-loss provisioning, credit growth limits, time-varying loan-to-value (LTV) or debt-to-income ratio (DTI), caps for loans.

The crisis revealed the need for macroprudential approach to financial system assessment. So far, regulators have implemented measures that refer to macro prudential measures on discretionary levels, while the introduction of macroprudential policies harmonizes and determines policy response to specific situations.

Finance is procyclical and is subject to booms/busts. Macro prudential policies are necessary to correct market failures and externalities and to compensate for microprudential policy causes. A strong institutional framework is necessary for smooth and effective functioning of a macro prudential policy.

International coordination of macroprudential policies is necessary for lowering cross border effect implications. Multilateral issues can arise from insufficient national actions, differences in the financial cycles in countries and conflicts between home and host authorities of cross border financial institutions. (IMF, 2013b)

\subsection{Key objective of macroprudential policy}

The key objective of macroprudential policy is to provide stability of the financial system as a whole by strengthening the resilience of financial system against shocks and preventing the build-up of systemic risks, therefore providing sustainable contribution of financial system to the economic growth. (ESRB, 2013a)

Macroprudential policy refers to identification, monitoring and assessment of systemic risks that can endanger financial stability. Macroprudential policies differ from financial and monetary policy in their instruments, even though the latter can also influence financial stability. Macroprudential supervision analyses in detail risks and stability situation within a financial system which allows communication of warnings against risks and imbalances as well as identification of potential actions to prevent danger. ${ }^{1}$

1 http://www.bundesbank.de/Navigation/EN/Tasks/Financial_and_monetary_system/Stability/Definitions/definitions.html 


\subsection{Before and after the crisis}

The importance of the financial stability and necessity for macroprudential policy came to the scene with the global financial crisis. Before the crisis, the importance of macroprudential policy was not that emphasized but situation has changed since the crisis. Authorities are now strongly dedicated to the creation of stable financial system that can identify risks in their early stages and is resistant to various shocks, both internal and external.

Central banks around the world were pushed to stabilize financial systems. As reaction to the global financial crisis, central banks cut interest rates and implemented non-standard measures of monetary policy. Before the crisis, central banks had the ultimate and primary objective - price stability, but the crisis revealed that not only monetary but also financial stability is necessary for sound financial systems and business circles. (DNB, 2015a)

Figure 1: Policies and objectives

How we saw the world before the financial crisis

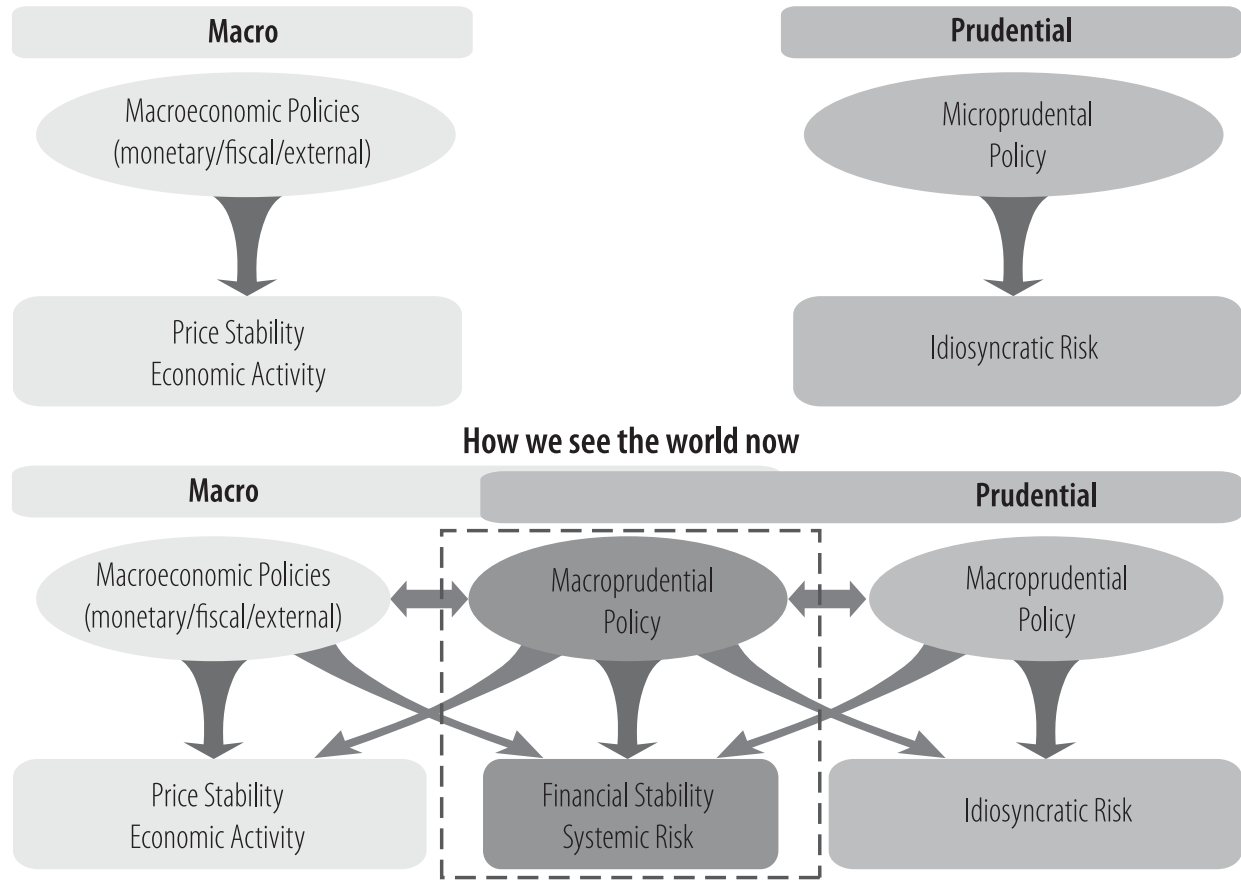

Source: IMF, "Interaction of monetary and macro prudential policies", Jan. 2013. 
In order to safeguard financial stability, it is very important to create a strong institutional framework, build effective macroprudential and other economic policies, as well as build up effective coordination among them.

The crisis showed that microprudential supervision alone cannot guarantee the financial system stability, because it does not take into account repercussions of development at the level of individual institutions on the entire financial system. (DNB, 2015a)

A common monetary policy (as in the case of euro area) cannot accommodate national "idiosyncraticities", therefore, it is very important to build adequate macroprudential policy and provide successful coordination with other economic policies.

By implementing measures of macroprudential policy, banks built higher quality capital buffers, reduced leverage, and improved their funding profiles.

\section{Macroprudential policy - Strong Institutional framework}

Responsibilities for macroprudential policy and macroprudential supervision defer among countries. Strong institutional framework is necessary to clarify objectives, to assign macroprudential policy mandates, to ensure timely and appropriate policy actions, to pose a guard to political pressures, to delay actions and provide legal foundation for using macroprudential policy. (Otker-Robe, Inci, 2015)

\subsection{Institutional framework}

It is necessary to create a strong institutional framework for successful implementation of macroprudential policy. In order to achieve objectives of macroprudential policy, research and experiences suggest that there are two risks that should be reduced: a) too much inaction should be avoided, while b) too much action can also create a problem. Too much inaction can cause difficulties to quantify the benefits of action vs. costs, result in lack of clear mandates and responsibilities as well as political interference. On the other side, too much action is risky because it can make governments tempted to use macroprudential policy to escape difficult policy choices. This implies that it would be more useful if other policies are placed to address imbalances and sources of systemic risks rather than sole macroprudential policy. (Otker-Robe, Inci, 2015) 


\subsection{Key aspects of operationalizing macroprudential policy}

There are five key aspects of macroprudential policy as illustrated in the picture below.

Picture 1: Five key aspects of macroprudential policy (MaPP)

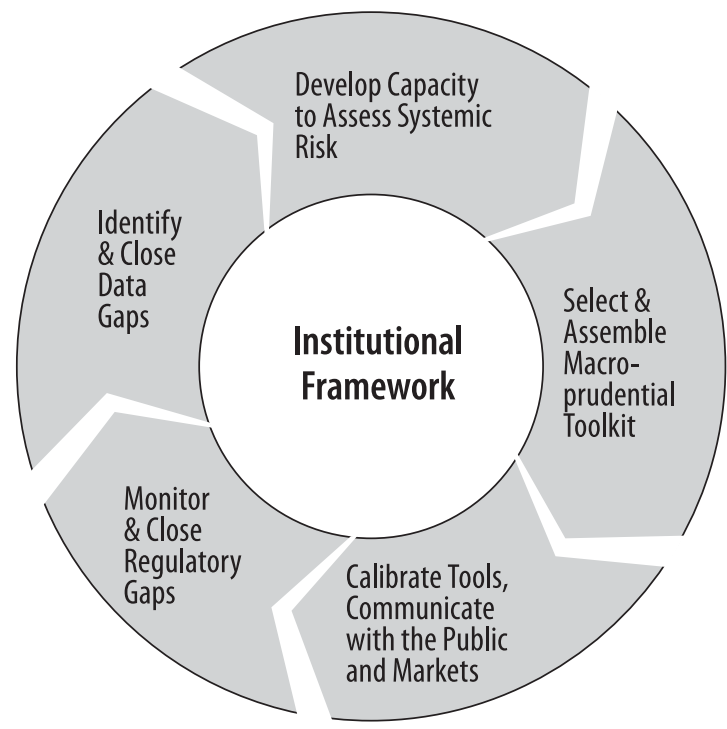

Source: International Monetary Fund, Key Aspects of Macro prudential Policies, IMF

The authorities should provide the capacity to assess systemic risks. Framework that is effective in monitoring the systemic risk is crucial for operationalizing macroprudential policy. The authorities need to select and assemble macroprudential instruments that can support identification of key potential sources and dimensions of systemic risks and should calibrate tools that are acquired, taking into account their benefits and costs, and communicating to the public their basis for policy decisions. The authorities need to monitor regulatory gaps and take actions in order to close them when it is necessary as well as to identify and close data gaps that can affect macroprudential analysis, calibration of macro prudential tools, and the detection of regulatory gaps. (Picture 1) (IMF, 2013b)

Strong and effective framework with defined principles is required for the operationalization of 5 key aspects of macroprudential policy. Therefore, strong institutional framework should (Chart 1): 
- Support the willingness to act. In order to provide timely and accurate use of macroprudential policy tools further principles must be satisfied: welldesigned objective, clarified mandates and powers assigned to someone as well as a strong role of central bank.

- Strengthen the ability to act. This refers to effective identification and monitoring of systemic risk. To ensure this, access to relevant information, usage of existing resources and expertise, powers to calibrate tools and mechanisms to challenge dominant views must be provided.

- Launch strong accountability and transparency. This requires internal and external checks and periodic assessment of effectiveness and costs.

- Ensure effective coordination with policies that also affect systemic risks, such as monetary, fiscal and microprudential policies. Interaction with monetary and micro prudential policy must be considered as well as the role of fiscal policy and structural policies. This is especially important when the power over tools is with other bodies. The autonomy of each of the policies must be ensured.

Chart 1: Principles for starting institutional framework

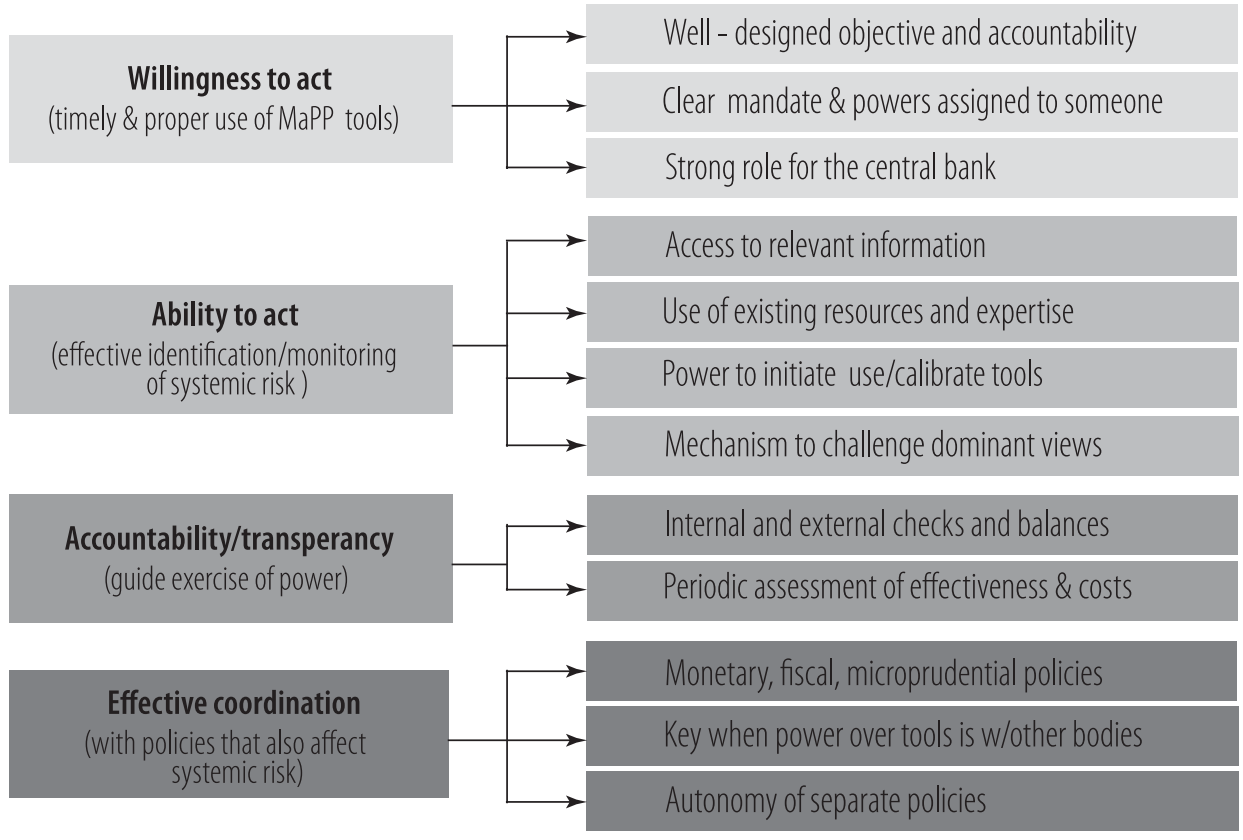

Source: Otker-Robe, Inci, Key Elements of Institutional Framework for MaPP, International Finance Discussion 


\subsection{Strengthening macro-prudential policy in Europe}

Macroprudential policy is a relatively new institutional set up in the euro area and the EU. Generally, responsibility for macroprudential policy in the EU lies with individual member states. However, the SSM was launched in November 2014. With the establishment of the single supervisory mechanism the ECB has become responsible not only for microprudential supervisory powers but also for certain macroprudential information and intervention rights in relation to the SSM member states. The ECB has been responsible for banking supervision in the SSM member states. Even though it has its own powers the ECB works in cooperation with the national supervisory authorities rather than performing all supervisory tasks itself. It is important to emphasize that the ECB is responsible for the direct control of those financial institutions that are classified as significant for the financial system stability. (EC, 2013)

The European Systemic Risk Board (ESRB) suggested recommendations on macroprudential policy and its objectives in 2011 and 2013. Identifying intermediate objectives makes macroprudential policy more operational, transparent and accountable and provides an economic basis for the selection of instruments. Recommendation of the ESRB from 2013 refers to the macroprudential mandate of national authorities by elaborating on intermediate objectives and instruments of macroprudential policy. It followed up on the Recommendation ESRB /2011/3 o of 22 December 2011 which refers to the identification of intermediate policy objectives as operational. The Recommendation ESRB/2013/1 has objective to take necessary steps towards an operational macroprudential oversight. (ESRB, 2013a)

Right time identification of potential problems or systemic risks is of high importance. Detailed analysis can provide a choice of adequate instrument or group of instruments that should be applied or excluded to mitigate risks or eliminate it. Macroprudential authorities should dispose with necessary powers to implement macroprudential instruments. There are various macroprudential instruments. They can be applied to broad or targeted categories of exposures, for example to foreign currencies and etc. Formatting prudential requirements in the form of regulation would ensure that those requirements would be directly applicable. According to this regulation, all institutions would follow the same rules. This would decrease regulatory complexity and firms' compliance costs and be especially beneficiary for companies that are operating cross border. (ESRB, 2013a)

The selection of instruments is done based on effectiveness and efficiency. Effectiveness refers to the level to which selected instrument can identify problems on 
the market and fulfil intermediate and key objectives. Efficiency refers to achieving objectives with the lowest possible costs.

Table 1: Intermediate objectives and instruments of macro-prudential policy

Intermediate objectives and instruments of macroprudential policy

1. Mitigate and prevent excessive credit growth and leverage:

1.1. CCB - Countercyclical capital buffer

1.2. Sectoral capital requirements

1.3. Macroprudential leverage ratio;

1.4. LTV requirements (Loat-to-value ratio)

1.5. LTI requirements (Loan-to-income ratio)

2. Mitigate and prevent excessive maturity mismatch and illiquidity

2.1. Macroprudential adjustment to liquidity ratio (liquidity coverage ratio - LCR);

2.2. Macroprudential restrictions on funding sources (net stable funding ratio - NSFR);

2.3. Macroprudential unweighted limit to less stable funding (loan-to-deposit ratio);

2.4. Margin and haircut requirements

3. Limit direct and indirect exposure concentrations

3.1. Large exposure restrictions

3.2. CCP (Central Counter Parties) clearing requirement

4. Limit the systemic impact of misaligned incentives with a view to reducing moral hazard

4.1. SIFI capital surcharges

5. Strengthen the resilience of financial infrastructures

5.1. Margin and haircut requirements on CCP clearing

5.2. Increased disclosure

5.3. Structural systemic risk buffer

Source: ESRB, RECOMMENDATION OF THE EUROPEAN SYSTEMIC RISK BOARD of 4 April 2013 on intermediate objectives and instruments of macro-prudential policy (ESRB/2013/1) (2013/C $170 / 01)$

The $\mathrm{ESRB}^{2}$ has identified four intermediate objectives that are relevant for safeguarding financial stability of the banking sector. Objectives are aimed at preventing and mitigating systemic risks that may arise from:

- excessive credit growth and leverage. Excessive credit growth is considered as the main source of financial crises. It is especially the problem when excessive credit growth is followed by unsustainable development on the real estate market, which leads to leverage in the private sector.

2 The ESRB was established in response to the financial crisis and it is responsible for macroprudential oversight of the financial system in the EU. Its aim is to prevent or mitigate systemic risks. Its main tasks are to collect and analyze all necessary data, identify systemic risks, issue warnings when systemic risk is identified, issue recommendations for remedial action in response to the risk identified, etc. 
- excessive maturity mismatch and market illiquidity. The crisis showed that implementation of prudential rules only on preserving credit risks (strengthening capital buffers) was not enough to prevent systemic risks and liquidity risk should have been more treated. There is a need to use liquidity instruments at the macroprudential level to mitigate liquidity risks. Presence of short term and illiquid sources can lead to fire sales, market illiquidity and contagion.

- direct and indirect exposure concentrations. This refers to exposure concentrations that make financial sector vulnerable to common shock. Direct concentration to specific sector or asset class can influence balance sheet. Indirect risk affects banks through asset fire sales and contagion;

- misaligned incentives with a view to reducing moral hazard. This refers to the systematically important institutions. The awareness that some institutions are too big to fail can lead to misaligned incentives and produces moral hazard. That is why it is very important to strengthen the resilience against potential shocks, while counterbalancing the negative effects of government guarantees.

- strengthen the resilience of financial infrastructures -The ESRB Recommendation on intermediate objectives and instruments of macro-prudential policy (ESRB/2013/1) also included this objective as the fifth one. When considering the banking sector, this objective should be omitted as it has been omitted from the Handbook on Operationalizing Macro-prudential Policy in the Banking Sector, because it is not included in the scope of the macroprudential framework for the banking sector, as provided under the CRD/CRR. (Table 1), (ESRB, 2013a, 2015a)

Since the Capital Requirement Directive/ Capital Requirement Regulation (CRD/ $C R R$ ) entered into force in 2014, the ESRB started to perform a review of macroprudential policy in the EU on a regular basis. With the introduction of the CRD/CRR, new global standards on bank capital, proposed through the Basel III agreement, entered into force. This was a way to set stronger prudential requirements for banks, requiring them to keep sufficient capital reserves and liquidity. A review of macroprudential policy in the EU one year after the introduction of the $C R D / C R R$ is the first comprehensive review of macroprudential policy in the EU. The introduction of CRD/CRR charged the ESRB with a number of new tasks and a new set of policy instruments that will help in identifying financial stability risks more effectively. This report describes the macroprudential measures adopted in the EU in this first year (that is, until end-2014) and draws some general conclusions. As expected, the measures almost exclusively cover the banking sector and, therefore, it was the focus of the report. According to the report, there are many Member States that pursued macroprudential policies in 2014. 
Around 100 measures were taken in that year, of which about half could be considered substantial. Due to the report, some of Member States were very active (e.g. Denmark, Slovakia, Sweden, United Kingdom). On the other hand, there are countries for which no measures were recorded such as France, Germany, Poland, Spain. Differences in the implementation may regard to different phases of the financial cycle the Member States were in, then different views on the role of macroprudential policy, whether or not a national macroprudential authority was already in place in the Member State concerned, and whether macroprudential measures had already been activated before the introduction of the CRD/ CRR. (ESRB, 2015b)

\section{Responsibility for macroprudential policy}

Responsibilities for macro prudential policy defers among countries. Though, it is very important to have clearly defined mandates for macroprudential policy. It is possible to identify three institutional models. There are possibilities of full or partial integration in the central bank or separate body responsible for macroprudential policy. Full integration means that the central bank is responsible for macroprudential policy in the country. In case of partial integration, there is a specific committee within the central bank. Third option is the organization of a separate body such as a committee outside the central bank.

Examples of full integration are macroprudential regimes in the Czech Republic, Serbia, Ireland, Estonia, etc. Example of partial integration is the UK (Bank of England). Responsibility for macroprudential policy is given to a separate body in France, Germany, Turkey, Bulgaria, etc. (Table 2)

Table 2: Three institutional models

\begin{tabular}{ccc}
\hline $\begin{array}{c}\text { Model 1 } \\
\text { Full integration }\end{array}$ & $\begin{array}{c}\text { Model 2 } \\
\text { Partial Integration }\end{array}$ & $\begin{array}{c}\text { Model 3 } \\
\text { Separate body }\end{array}$ \\
\hline Czech Republic & Hong Kong & Australia \\
Ireland & Malaysia & France \\
New Zealand & Thailand & Germany \\
Serbia & Romania & Turkey \\
\hline Singapore... & UK & US ... \\
\hline
\end{tabular}

Source: Otker-Robe, Inci (2015), Key Elements of Institutional Framework for MaPP, International Finance Discussion Papers 1136, BIS-CBRT-IMF Conference on Macro prudential Policy 
There is no perfect model. Each of them has some weaknesses and strengths. However, the choice of model depends also on legal framework, history, size of financial system, among other reasons. Still, there are some features that should be met no matter which model is in question. Those are: clear mandates and ensured accountability, major role of the central bank, and safeguarding central bank independence. (Otker-Robe, Inci, 2015)

Central bank should have a significant role in macroprudential policy regardless of the type of institutional model. The reasons are expertise in systemic risk identification, incentives to pursue macro prudential policy effectively, and it is less prone to be affected by political pressures.

\section{Relationship between macroprudential and other policies}

In order to create a strong and stable financial system, besides strong macroprudential policy, the relationship of macroprudential with other economic policies must be considered. Various circumstances and problems arising from the field of other policies can spill over to the financial sector and affect its stability. Coordination among policies leads to synergies that contribute to the efficient and effective achievement of their objectives. Figure 2 shows the connection between macroprudential and other policies.

Figure 2: Relationship between Macroprudential and Other Policies

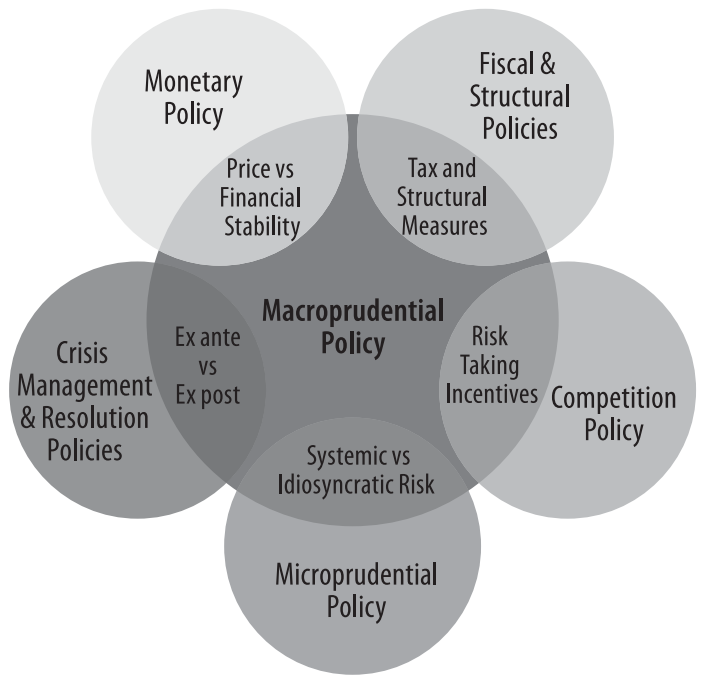

Source: IMF (2013) "Key Aspects of Macroprudential Policy“, IMF, Washington 


\subsection{Relationship between macroprudential and monetary policies}

Ideal situation would be the one in which macroprudential policy is targeting the sources of threats to financial stability as well as monetary policy that remains focused on its primarily goal - price stability. Policy makers face problems with the so-called side effects that can grow from the relationship between monetary and macroprudential policies. These interactions can reduce effectiveness in obtaining objectives of each of the policies. That is why it is very important to provide coordination among them.

The strengthening of the banking system's resilience reduces the effects of implementing a restrictive monetary policy. Well calibrated and clearly communicated macroprudential policies can be very effective, identify and mitigate risks ex ante and therefore limit the burden to the monetary policy. Macroprudential tools can provide buffers in order to avoid unexpected shocks, thus lessening the risk to the monetary policy will run into the lower bound on interest rates. (IMF, 2013a)

Changing in monetary stance affects the financial sector. Monetary easing relaxes policy constraints, asset prices rise and borrowers net worth increase, lowers the external finance costs and ease generally credit conditions. On the other hand, tightening policy has adverse effect and can lower borrowers' capacity to repay, which can lead to financial instability. Monetary policy can affect asset prices and exchange rate externalities, therefore affecting the value of collateral, which influences the tightening of borrowing constraints. Asset prices have tendency to increase in the case of low interest rates, which can trigger excessive leverage and lead to price booms. On the contrary, a tightening monetary stance can cause collateral constrains to bind with creating adverse asset price externalities. (IMF, 2013a)

Theoretical literature suggests that monetary and macro prudential policies are complementary and not the substitutes, while the results depend on the type of shocks. Theoretical models within borrower collateral constraints and the banking sector consider that monetary policy controls the risk free interest rate while the macroprudential policy controls the risk premium. As long as the objectives are output and price stability, while implementing different policy rules and shocks (financial, productivity, demand), the literature typically concludes that the most optimal solution is to use both monetary and macroprudential policies.

According to these considerations, in the case of financial shock that is endangering financial stability, it is expected to use macroprudential policies as long as they are more targeted to the specific sector concerns. In the case of productiv- 
ity shock, it depends on the type of the shock, if the problems are laying in the borrower's collateral then it is enough to implement monetary policy. On the other side, if the problem is endogenous in the financial sector, then lending of individual bank affects the system and it is more relevant to use macroprudential policy measures and tighten the policy. (IMF, 2013a)

However, monetary policy should be dedicated to its objectives, it is best for all parties that it delivers its mandate. There are situations when financial stability concerns should be addressed by some other policies that are more related to the task than monetary policy. In order to improve financial regulation and supervision to make their financial systems more resilient to external shocks, countries can, for example, adopt their fiscal policies. (ECB, 2016a)

\subsection{Relation of macroprudential with fiscal and structural policies}

Financial stability can be strongly affected by the macroeconomic imbalances, because macroeconomic shock can spill over to the financial system and jeopardize stability. Appropriate fiscal and structural policies are important for minimizing the potential for macroeconomic shock.

In the occasions when the consumption boom is followed by a high current account deficit, macroprudential policy measures cannot be effective in resolving the situation, so here it is important to implement prudent fiscal and structural policies.

Fiscal policies can create a stimulus to economic recovery introducing lower taxation and better public investments while structural policies can support situation by creating better business conditions and public infrastructure. (ECB, 2016a)

After the crisis, countries implemented various measures of fiscal consolidation in order to lower public debt, keep it at sustainable levels while providing macroeconomic stability. Existence of strong fiscal policy is necessary in order to provide the safety of sovereign debt and to avoid adverse feedback loops between sovereign debt and financial system. (IMF, 2013b)

For example, regarding tax policy, the problem can arise because tax policies can create prejudice that can contribute to systemic risks while macroprudential authorities are trying to correct these biases. For example the tax treatment for housing can make households more exposed to the shock because some countries do not pose tax on rent thus providing relief for mortgage interest and households are encouraged to borrow. High mortgage debt can make households more 
vulnerable to shocks thereby creating a transmission channel to the financial crisis. (IMF, 2013b)

\subsection{Macroprudential and competition policies}

It is important to have correlation between the competition policy and systemic risks. The best way to implement it is the traditional way of competition policy which means to assign licencing, take over control, and break up powers to the prudential authorities.

When financial institutions merge or take over they can become very large and difficult to control, so called too big to fail, which means that their problems or ultimate bankruptcy would endanger financial stability. Another possibility is to create strong coordination between prudential and competition policies. (IMF, 2013b)

\subsection{Macroprudential and microprudential policies}

Microprudential and macroprudential policies should work in strong correlation. High quality and effective supervision is important not only for individual institutions but for entire financial systems. Information sharing, joint analyses of risk, and good communication.

There are situations when microprudential and macroprudential authorities have consolidated attitude while in some specific "bad times" they usually have confronted opinions. Macroprudential authorities may ask for relaxed regulatory requirements which affect the provisions on credits while microprudential authorities would prefer tightening of requirements in order to protect the interest of depositors of individual banks. In order to avoid such situations, macroprudential policy should establish sufficient capital buffers and then the tensions between policies would be relieved. Then, even if macroprudential authority is reducing capital buffers, it can be done the way that fits the stands of microprudential authorities. (IMF, 2013b)

\subsection{Relation between macroprudential and crisis management and resolution policies}

Crisis management and resolution policies are complementary to macroprudential policy. Crisis management calls for further requirements such as mon- 
etary easing, emergency liquidity assistance by central bank, resolution of failing banks, public guarantees and capital support provided by fiscal authorities.

Effective crisis management requires strong coordination among financial authorities. Macroprudential authorities are supposed to provide advice, suggestions, assess the level and sources of systemic risks and propose instruments that should be implemented. Fiscal authorities should coordinate policy response if there is a need for using taxpayer money.

Creating proper resolution plans and regimes serve as a precondition for fulfilling goals of macroprudential policy by strengthening market discipline and reducing the need for macroprudential interventions. (IMF, 2013b)

\section{Shadow Banking}

Shadow banking came to the stage after the 2008 crisis. This non-banking sector is important to emphasize because it performs important functions in the financial system as long as it creates additional sources of funding and offers investors alternatives to bank deposits thus it can pose potential threats to long-term financial stability. (EC, 2012) As long as it provides deposits it means that problems in this sector can result in massive deposit withdrawal, which can jeopardize financial stability.

Therefore, there is a strong need for regulating this area of financial activities. Shadow banking refers to the system of credit intermediation that involves entities and activities outside the regular banking system. Shadow banks are not regulated like banks even though they engage in bank-like activities. The latter has not been the focus of prudential regulation and supervision.

At the November 2010 Seoul Summit, the G20 Leaders identified some remaining financial sector issues which attract attention and highlighted "strengthening regulation and supervision of shadow banking" as one of these issues and requested the Financial Stability Board to develop recommendations to strengthen the oversight and regulation of the "shadow banking system", in collaboration with other international standard setting bodies. As response to this, the Financial Stability Board released a report on strengthening oversight and regulation of shadow banking. (EC, 2012)

In this context, in order to ensure more transparency on financial markets, the European Parliament (October 2015) adopted the Regulation on Transparency of 
Securities Financing Transactions (known as SFTR). This new regulation, proposed by the European Commission in January 2014, significantly improves the transparency of securities financing transactions in the shadow banking sector. These new rules also refer to the identification of risks associated with these financial transactions. This regulation is in line with the G20 leaders' commitment to provide more transparency on financial markets. (EC, 2015a)

To prevent banks from shifting parts of their activities to the less regulated shadow banking sector, measures must be accompanied by provisions improving the transparency of shadow banking. A better monitoring of these transactions is necessary to prevent the systemic risk and safeguard financial stability.

Shadow banking can be useful for the economy since it diversifies sources of financing but still there is international consensus that such activities should be transparent and subject to appropriate regulation.

\section{Final remarks}

The financial crisis revealed the need for macroprudential approach to the financial system assessment and the necessity for creating and implementing a strong macroprudential policy that will identify risks and support the prevention of the financial system from system shocks and make it more resilient. Before the crisis, macroprudential policy was not considered that important. Importance of financial stability as well as macroprudential policy came to the scene after the last financial crisis.

It is necessary to create a strong institutional framework for successful implementation of macroprudential policy. As explained, there are five key aspects of macroprudential policy that should be satisfied.

In order to achieve its key objective, the financial system stability, macroprudential policy has to be precisely determined with clearly defined mandates among responsible institutions. Responsibilities for macroprudential policy defer among countries. Regardless of the type of institutional model, central banks should have a significant role in macroprudential policy.

Even though macroprudential policy is very important for strengthening the financial system resilience to shocks, it cannot do it solely. Therefore, effective coordination with other policies is necessary. There are situations when the implementation of monetary, fiscal or other economic policies is more relevant and 
crucial for solving the problem, and the macroprudential policy is not individually sufficient to mitigate risks or prevent specific situation.

So far, macroprudential policies have been focused on banks but now it is clear that building a strong supervision only over the banking system is not enough and there is a need to expand the supervision especially to the non-banking sectors in order to safeguard financial stability. Responsible international institutions have already worked on regulation and institutional solutions in order to increase transparency and supervision of the non-banking sectors. The lack of supervision over this part of the financial system can affect financial stability.

We can conclude that macroprudential approach to the financial system assessment is necessary for a sound functioning of the financial system and safeguarding financial stability. 


\section{References:}

1. Akinci, Ozge, Olmstead-Rumsey, Jane (2015), How Effective are Macro prudential Policies? An Empirical Investigation, Board of Governors of the Federal Reserve System, Retrieved from: http://www.federalreserve.gov/ econresdata/ifdp/2015/files/ifdp1136.pdf

2. Deutsche Bundesbank (2015a), Monthly Report, The importance of macroprudential policy for monetary policy, DNB

3. Deutsche Bundesbank, Financial_and_monetary_system, Retrieved from: http://www.bundesbank.de/Navigation/EN/Tasks/Financial_and_ monetary_system/Stability/Definitions/definitions.html, DNB

4. European Systemic Risk Board, Retrieved from: http://www.esrb.europa. eu/about/tasks/html/index.en.html

5. European Central Bank (2016a), How Central Banks Meet the Challenge of Low Inflation, ECB, Retrieved from: https://www.ecb.europa.eu/press/key/ date/2016/html/sp160204.en.html

6. European Commission (2012), Green paper, Shadow banking, Brussels, Retrieved from: http://ec.europa.eu/finance/bank/docs/shadow/greenpaper_en.pdf

7. European Commission (2014), Press Release, Retrieved from: http://europa. eu/rapid/press-release_IP-14-85_en.htm?locale=en

8. European Commission (2015a), Press Release, Retrieved from: http:// europa.eu/rapid/press-release_IP-15-5930_en.htm

9. European Commission (2015b), Press Release, Retrieved from: http:// europa.eu/rapid/press-release_IP-15-5210_en.htm?locale=en

10. European Commission (2013), Press Release, Retrieved from http://europa. eu/rapid/press-release_MEMO-13-781_en.htm

11. European Systemic Risk Board (2013a), Recommendation of European Systemic Risk Board of 4 April 2013 on intermediate objectives and instruments of macro-prudential policy (ESRB/2013/1) (2013/C 170/01), ESRB

12. European Systemic Risk Board (2015a), European System of Financial Supervision, The ESRB Handbook on Operationalizing Macro-prudential Policy in the Banking Sector, ESRB

13. European Systemic Risk Board (2015b), European System of Financial Supervision, A review of macro-prudential policy in the EU one year after the introduction of the CRD/CRR, ESRB

14. International Monetary Fund (2013a), Interaction of Monetary and macroprudential policies, IMF

15. International Monetary Fund (2013b), Key Aspects of macroprudential Policies, IMF 
16. Otker-Robe, Inci (2015), Key Elements of Institutional Framework for MaPP, International Finance Discussion Papers 1136, BIS-CBRT-IMF Conference on Macro prudential Policy: Effectiveness and Implementation Challenges", İstanbul, Turkey, October 26-27, 2015, IMF Retrieved from: https://www.google.me/?gws_rd=ssl\#q=KEY+ASPECTS+OF+MaPP\%2C+I $\mathrm{MF}+2014$

17. Regulation (EU) No 575/2013 of the European Parliament and of the Council of 26 June 2013 on prudential requirements for credit institutions and investment firms and amending Regulation (EU) No 648/2012 (Text with EEA relevance), Retrieved from: http://eur-lex.europa.eu/legal-content/ EN/TXT/?uri=CELEX\%3A32013R0575 